\title{
SIGNIFICANCE \\ OF EMOTIONAL INTELLIGENCE \\ IN LEADERSHIP
}

\author{
Kamila Skrzypczyńska
}

Nicolaus Copernicus University in Torun, Torun, Poland

e-mail: k_skrzypczynska@econ.umk.pl

\begin{abstract}
Purpose: The main purpose of the article is to present theoretical assumptions of emotional intelligence and its influence on leadership challenges. The article presents the evolution of the leadership concepts and the most important models of emotional intelligence in order to identify the attributes that influence leader effectiveness and the role of emotional intelligence in leadership.
\end{abstract}

Methodology: The article has been written following a careful review of leading literature of the subject and in accordance with the logics of resource-based view.

Conclusions: Emotional intelligence is of high significance in leadership and its level affects the quality of collaboration and fosters networking based on healthy relationships. A manager with a high EQ consciously and effectively creates a work atmosphere that supports solving problems, and his/her ability to control own and others' emotions builds trust and encourages creativity, development, and even committing mistakes, thus creating a sustainable, success-oriented organisational culture.

Originality/Value: This article contributes to further discussion on the role of emotional intelligence in leadership. The very concept of emotional intelligence and its internal structure is still evolving, just as it is in the case of leadership. As a result, the dynamics of both areas, their interdependence and varying attitudes of scientists make it difficult to identify a precise boundary defining the extent to which emotional intelligence determines leader effectiveness, which even more encourages further research and extrapolation of these areas.

Keywords: leadership, emotional intelligence, models of emotional intelligence

Paper type: General review

The current business environment in which enterprises operate is changing in a way never before seen in the history of human civilisation and a new leader is generally expected to introduce fundamental changes in the organisation and to solve its most pressing problems in the first place. Nevertheless, leadership opportunities are severely limited by its organisational context: structure, power distribution, environmental conditions, team, etc. Although the role of the leader is seen in a variety of ways and everyone creates a different image of a perfect 
leader, there is a group of basic attributes that a good leader should have as they significantly influence the final result achieved by the team.

Years of research into the phenomenon of leadership have resulted in numerous theories and models. Initially, leadership was linked to definite personality traits. Basing on life paths of outstanding individuals, a correlation between specific qualities and success was explored and, consequently, personality-based leadership models were developed (Aitken and Higgs, 2010; Hernez-Broome and Hughes, 2004). The next step in the development of leadership focused the attention of researchers on sources of authority and the way they are utilised. Hence, this stage is referred to as the era of influence. Scientific considerations oscillated around the types of influence and the possibility of using it in the managerial practice. In subsequent studies on leadership the focus was on the analysis of behaviours of effective and ineffective leaders with the purpose of creating a list of desired leadership behaviours. The research conducted at that time aimed at determining leadership styles and leadership behaviour towards employees; the example being the research of K. Levin, R. Tannenbaum and W.H. Schmidt, the model of R. Blake's and J. Mouton's managerial grid (Fleishman et al., 1991; Northouse, 2003). Subsequently, researchers began to give more importance to the context in which the leader functions, in terms of the team with which they work and other organizational resources. This led to the development of situational leadership in which the leader selects the most effective style depending on the external situation. F.E. Fiedler's contingency theory, the situational leadership model by P. Hersey and K.H. Blancharad, and the LMX exchange theory were created as part of this trend (Hersney and Blanchard, 1996; Fiedler, 1995). The summary of these considerations was, in a sense, the next stage called the contingency era. At this stage, researchers reached a consensus and established that leadership depended on at least one factor that comes respectively from the group of personality, influence, behaviour or situation. Contingency leadership has been complemented over time by areas of social interaction and thus defined as transactional leadership. Leadership effectiveness is based on the skills of the leader but also on the expectations of employees themselves as presented in the M.B. Bass model (Bass, 1990). Later attempts to explain the phenomenon of leadership led researchers to the extreme perception of the concept; voices undermining the sense of leadership research appeared in the community, and there followed an era of anti-leadership during which even substitutes for leadership were proposed. This stage did not last long and there came a turn in thinking about leadership. The importance of a leader in shaping organisational culture, that would allow employees to become independent and encourage them to be their own leaders, was soon recognised.

The penultimate stage is the transformational era which analyses behaviours of leaders who are a driving force of a change and shape the vision of the organization in the context of uniting employees for a common cause (Seters and 
SIGNIFICANCE OF EMOTIONAL INTELLIGENCE

Kamila Skrzypczyńska
Field, 1990). Hundreds or even thousands of studies and analyses of leadership have led researchers to many theories and concepts falling within the above trends (Zaren et al., 2014). The last paradigm is organic leadership, which focuses on communication between all team members. This idea assumes that leadership emerges from a common relationship between co-workers, who are able to jointly interpret the environment and create common values.

The role of emotional intelligence in leadership has been recognised (compared to the period of considerations on leadership) relatively recently. Emotional intelligence is the ability to perceive, understand, and exploit emotions with all their strength and dynamism in order to build relationships and influence as well as to use emotions as the source of information and energy (Salovey and Mayer, 1999). This approach perfectly illustrates the importance of competences arising from EQ in effective leadership.

The literature on the subject is dominated by three most popular models of emotional intelligence, i.e. the Goleman model, the Bar-On model and the Salovey and Mayer model. The first two are mixed in character, which means that they qualify for emotional intelligence elements from the group of both cognitive abilities and personality traits. The third one is exclusively skills-based and has the most scientific character.

In the Goleman model, who himself is considered to be the greatest populariser of emotional intelligence, EI is a unique foundation, "another kind of wisdom", on which traditional intelligence can be developed. In determining the structure of emotional intelligence, Goleman defined 5 areas (Goleman, 1999; Goleman, 1990). The first one refers to the understanding of emotions through conscious perception in order to manage one's own emotions to a certain degree; the subsequent step concerns the management of emotions. It should be understood as the ability to calm oneself down, to manage emotions so that they are right and to be able to eliminate negative feelings. The third area concerns self-motivation and entails the identification of emotions useful for achieving the goal, deferring gratification, limiting impulses and readiness to succumb to changing moods. While the first three areas refer to intrapersonal issues, the last two relate to the environment. The fourth area is the recognition of other people's emotions through empathic awareness or ability to tune in while the fifth area involves maintaining interpersonal relationships through the ability to regulate others' emotions and to interact easily.

In the model defined by Bar-On, emotional intelligence is based on five key extra-cognitive skills, i.e. 1) intrapersonal skills such as emotional self-awareness, assertiveness, self-reliance, self-regard, self-actualization; 2) interpersonal skills including elements such as empathy, interpersonal relationships, and social responsibility; 3) adaptability skills comprising flexibility, the ability to confront subjective experiences with reality, and the ability to solve problems; 4) ability 
to cope with stress including impulse control and stress tolerance; 5) general optimism with a positive attitude and a sense of happiness (Bar-On, 1997; BarOn, 2001). When defining emotional intelligence, Bar-On refers to its importance in effectively coping with the demands and pressures of the environment by using a range of non-cognitive competences, skills, and abilities.

Both models mentioned above are mixed in nature and are often the subject of critical discussion in the scientific community due to the fact that they comprise social competences, abilities, and personality traits, i.e. they define emotional intelligence that goes beyond the skill-based predispositions. The sharpest voices express the view that emotional intelligence defined in this way does not bear the traits of intelligence. The research methodology itself and the empirical data obtained in the course of research, both in quantitative and qualitative terms, are also subject to criticism (Mayer et al. 2001; Neubauer and Freudenthaler, 2005).

The last of the discussed models, emotional intelligence based entirely on skills, is presented by Salovey and Mayer whose conception focuses on the capability to think about emotions and to process emotional information with the purpose of supporting and improving cognitive processes. The authors believe that emotions are a specific response of the human body, the response that is filtered through a series of psychological subsystems containing physiological, cognitive, motivational, and experimental elements (Mayer and Salovey, 1999). They define emotional intelligence by identifying four groups of capabilities of a cognitive character (Mayer and Salovey, 1999):

1. Perceptions, assessment, and expression of emotions - this group of abilities concerns mainly the precision with which an individual is able to recognize emotions. It forms the basis of emotional intelligence and includes the ability to identify one's own emotions and recognise them in other people, the ability to identify emotions in works of art, the ability to express one's own emotions properly, and the ability to distinguish between true and false as well as adequate and inadequate emotional information.

2. The second group of abilities is the emotional support for reasoning aimed at including emotions in the process of rational problem solving in order to increase its effectiveness. The second level of emotional intelligence requires mastering the ability to change the direction of thinking and to redirect attention towards the right priorities; it resorts to generating emotions for a better understanding of the past and the future, using mood changes to adopt different reasoning perspectives and problem-solving approaches.

3. The third group consists of the abilities connected with the understanding and analysis of emotions. At this level it is necessary to precisely identify the source of the emotion which consequently allows to predict emotions 
SIGNIFICANCE

OF EMOTIONAL

INTELLIGENCE

Kamila Skrzypczyńska
Table 1.

Leadership attributes resulting from high levels of emotional intelligence

Source: own elaboration. that can arise. The authors qualified for this group the ability to adequately name emotions and to understand the relation between words and emotions, to give meaning to the emotions experienced and to interpret them correctly as regards their relationship with the environment, to understand complex (sometimes contradictory) emotions, to anticipate probable changes in emotional states.

4. The last group of abilities signifies the highest level of proficiency in this matter - reflective regulation of emotions. It is characterised by awareness and is based on full acceptance of one's own emotions and those of others. Reflective regulation of emotions requires first of all the ability to accept both pleasant and unpleasant emotions, the ability to engage or disengage knowingly from specific emotions, depending on their value, and to consciously monitor emotions within the self and in relationships with others, to finally control emotions of the self and others by neutralizing negative emotions and strengthening positive ones.

There is much evidence in the literature on the subject that emotional intelligence is an important source of leaders' success and allows them to perform their role more efficiently and effectively. The following is an overview of research confirming how many important leadership attributes result from developed emotional intelligence.

\begin{tabular}{ll}
\hline $\begin{array}{l}\text { Leadership } \\
\text { attributes }\end{array}$ & Description \\
\hline Composure & $\begin{array}{l}\text { Emotionally intelligent leaders are highly aware of their emotions and able to } \\
\text { control and use them in performance to be more effective (Azouzi and Jarboui, } \\
\text { 2013). }\end{array}$ \\
\hline Smartness & $\begin{array}{l}\text { Leaders with developed emotional intelligence use their time more effectively } \\
\text { and adapt their behavior to a specific situation and better solve complex pro- } \\
\text { blems as a result (Yukl, 2010). }\end{array}$ \\
\hline Conscientio- & $\begin{array}{l}\text { As part of praxeological skills that form emotional intelligence of leaders, there } \\
\text { is conscientiousness that is expressed in goal-oriented activity and perseverance } \\
\text { in their implementation as well as in great meticulousness and detail. Conscien- } \\
\text { tious leaders set themselves ambitious goals in life and work; they are rational } \\
\text { in interpersonal relationships and decision-making (McCrae and Costa, 2005). }\end{array}$ \\
\hline Authority & $\begin{array}{l}\text { Emotional intelligence facilitates the adoption of a broad perspective on thin- } \\
\text { king. Leaders with a developed emotional intelligence are thus able to use their } \\
\text { emotions to avoid loss of position or reputation, which means they are more } \\
\text { effective in crisis situations (Azouzi and Jarboui, 2013). }\end{array}$ \\
\hline Amicability & $\begin{array}{l}\text { Developed emotional intelligence causes leaders to be more lenient, polite, empa- } \\
\text { thic and more often helpful to others. They also avoid conflicts, are more coope- } \\
\text { rative and do well in work that requires positive interpersonal relations. Amica- } \\
\text { bility is associated positively with job satisfaction (Judge and LePine, 2007) and } \\
\text { negatively with deviant and counter-productive behaviour (Salgado, 2002). }\end{array}$ \\
\hline
\end{tabular}




\begin{tabular}{|c|c|}
\hline $\begin{array}{l}\text { Leadership } \\
\text { attributes }\end{array}$ & Description \\
\hline $\begin{array}{l}\text { Stress resi- } \\
\text { stance }\end{array}$ & $\begin{array}{l}\text { Intrapersonal skills associated with developed emotional intelligence provide } \\
\text { a high level of emotional stability. Such leaders are characterized by calmness, } \\
\text { composure and the ability to react constructively. They do not often experience } \\
\text { negative emotions like anxiety or stress (McCrae and Costa, 2005). Lower le- } \\
\text { vels of stress in leaders are associated with feelings of wellbeing, job satisfac- } \\
\text { tion and job retention, as well as better handling of individual and organizatio- } \\
\text { nal failures (Salgado, 2002, Judge and LePine, 2007, Judge et al., 2009). }\end{array}$ \\
\hline $\begin{array}{l}\text { Leadership } \\
\text { flexibility }\end{array}$ & $\begin{array}{l}\text { It has been proven that managers with a high level of emotional intelligence } \\
\text { prefer more effective management styles to those with a lower level of emotio- } \\
\text { nal intelligence (Opolska, 2014; Fiedeldey-Van Dijk and Freedman, 2007). }\end{array}$ \\
\hline Openess & $\begin{array}{l}\text { Emotionally intelligent leaders are characterized by cognitive curiosity, ima- } \\
\text { gination, unconventional thinking and a tendency to experiment, i.e. openness } \\
\text { in a broad sense. They are usually nonconformists with an anti-authoritarian } \\
\text { and anti-institutional approach (McCrae and Costa, 2005). These attributes are } \\
\text { useful in creative, conceptual, and design work in innovative organisations. }\end{array}$ \\
\hline Adaptability & $\begin{array}{l}\text { Emotional intelligence of leaders translates into the ability to adapt to new } \\
\text { conditions, solve difficult problems effectively and create bold visions for the } \\
\text { company (Judge et al., 2009) }\end{array}$ \\
\hline Efficiency & $\begin{array}{l}\text { A number of attributes associated with emotional intelligence make such le- } \\
\text { aders more efficient in their work and better manage their own time and that of } \\
\text { their employees (Kerr et al., 2006). }\end{array}$ \\
\hline Extraversion & $\begin{array}{l}\text { Emotionally intelligent leaders are usually assertive, active, energetic, optimi- } \\
\text { stic and sociable. They more often experience positive emotions and general } \\
\text { well-being (McCrae and Costa, 2005). Research shows that these characteristics } \\
\text { strongly correlate with effectiveness in selling and managing people (Barrick et } \\
\text { al., 2001; Judge et al., 2009). }\end{array}$ \\
\hline Effectiveness & $\begin{array}{l}\text { Leaders with developed emotional intelligence know how to use the right } \\
\text { emotions to act effectively, and how to be unmanaged by emotions that do not } \\
\text { contribute to the goal (Azouzi and Jarboui, 2013). }\end{array}$ \\
\hline $\begin{array}{l}\text { Building cli- } \\
\text { mate for work }\end{array}$ & $\begin{array}{l}\text { Emotionally intelligent leaders usually use a rewarding style, clearly defining } \\
\text { expectations and promoting a fair climate and constructive working conditions } \\
\text { (Judge et al., 2009). }\end{array}$ \\
\hline $\begin{array}{l}\text { Conflict mana- } \\
\text { gement }\end{array}$ & $\begin{array}{l}\text { Emotional intelligence makes it possible for such leaders that, when working } \\
\text { with others, they are able to recognize emotions and react appropriately when } \\
\text { they see that an escalation of emotions can lead to conflict (Azouzi and Jarboui, } \\
\text { 2013). }\end{array}$ \\
\hline
\end{tabular}

SIGNIFICANCE OF EMOTIONAL INTELLIGENCE

Kamila Skrzypczyńska

Table 1.

Continued 
SIGNIFICANCE OF EMOTIONAL INTELLIGENCE

Kamila Skrzypczyńska results primarily from the fact that managers with high EQ fit into the profile of the desired leadership model. Such leaders are characterized above all by following clearly defined principles and values, self-discipline, honesty, consistency. They can question even most important issues since they create the environment and even reveal the desire that such a situation serves progress. They are creative, engage in critical disputes and strive for a dialogue and responsible decisionmaking (Dabke, 2016). As numerous studies show, emotional intelligence helps the leader to (Gandolfi and Stone, 2016; Kaplan, 1991; Salovey and Mayer, 1990; Salovey, 2001; Goleman, 2006, Ciarrochi et al. 2000; Ciarrochi et al. 2001):

- shape positive emotions in relations with others and thus to foster a friendly organizational climate and build an atmosphere of trust,

- act with awareness and empathy even in difficult situations,

- build organizational culture based on trust and good will through transparent presentation of values in one's own activities,

- achieve goals by honest and effective involvement of others in their implementation, shape a high level of employee involvement and identification with the organization, create messages, mottos or presentations that have an illustrative and convincing impact on the recipient, motivating them to act,

- identify important issues that form the background for interaction and utilise this information in management processes,

- build the authority and trust of the team based on their own professional and personal integrity,

- resolve or even prevent conflicts by identifying potential sources of ignition,

- effectively identify communication gaps and implement countermeasures to improve communication, honestly and transparently communicate with subordinates,

- see the potential despite unobvious connections and have the courage to undertake challenges and persevere with goals.

According to the leaders of the world's largest companies, the significance of emotional intelligence is growing. Relating the presented models of emotional intelligence to the results of research published in the book Perspektywy rozwoju przywództwa w biznesie korporacyjnym (Perspectives for Leadership Development in Corporate Business) (Karaszewski et al., 2019), one can notice that over the last 10 years the level of importance of cognitive skills in the field of emotional intelligence has generally increased, although not proportionally to the level of popularization of this phenomenon among a wider group of recipients. The key problem taken up in the survey was to identify the most desirable features and competences of the leader, which the respondents had to select and assess. The cafeteria of questionnaire indications contained 42 items and was elaborated on 
the basis of the results of research conducted by Stogdill, Mann, Lord, DeVader and Alliger, Kirkpatrick and Locke, Kouesses and Posner, among others. The survey conducted in 2018 is the repetition of the survey carried out ten years before and its results present the transformation of beliefs about leadership among leaders of the largest corporations [1].

The analysed qualities included classic personality traits such as ambition, determination, honesty or loyalty, juxtaposed with cognitive abilities that correspond to the presented models of emotional intelligence such as selfawareness, self-control, self-confidence, motivation, ability to inspire others, performance orientation, willingness to collaborate, ability to exert influence, empathy, ability to adapt. Detailed results are presented in Table 2.

\begin{tabular}{lll}
\hline \multirow{2}{*}{ Quality or skill of a leader } & Primary results & Results 2018 \\
\cline { 2 - 3 } $\begin{array}{l}\text { percentage } \\
\text { of indications }\end{array}$ & $\begin{array}{l}\text { percentage } \\
\text { of indications }\end{array}$ \\
\hline credibility, integrity & $38.29 \%$ & $\mathbf{5 5 . 8 8 \%}$ \\
\hline ability to inspire others & $41.44 \%$ & $\mathbf{4 6 . 0 8 \%}$ \\
\hline honesty & $40.09 \%$ & $\mathbf{4 2 . 1 6 \%}$ \\
\hline accountability & $40.54 \%$ & $\mathbf{4 1 . 1 8 \%}$ \\
\hline results orientation & $34.23 \%$ & $\mathbf{3 9 . 2 2 \%}$ \\
\hline determination & $47.30 \%$ & $\mathbf{3 9 . 2 2 \%}$ \\
\hline motivation & $30.63 \%$ & $\mathbf{3 8 . 2 4 \%}$ \\
\hline ability to look ahead to the future & $47.30 \%$ & $\mathbf{3 7 . 2 5 \%}$ \\
\hline broad horizons & $29.73 \%$ & $\mathbf{3 6 . 2 7 \%}$ \\
\hline willingness to collaborate & $26.13 \%$ & $\mathbf{3 2 . 3 5 \%}$ \\
\hline self-awareness & $24.32 \%$ & $\mathbf{3 2 . 3 5 \%}$ \\
\hline ability to influence others & $36.49 \%$ & $\mathbf{3 0 . 3 9 \%}$ \\
\hline supporting others & $27.48 \%$ & $\mathbf{3 0 . 3 9 \%}$ \\
\hline self-discipline, self-control & $23.87 \%$ & $\mathbf{3 0 . 3 9 \%}$ \\
\hline showing initiative & $31.53 \%$ & $\mathbf{2 9 . 4 1 \%}$ \\
\hline self-confidence & $31.08 \%$ & $\mathbf{2 9 . 4 1 \%}$ \\
\hline objective pursuit & $31.98 \%$ & $\mathbf{2 9 . 4 1 \%}$ \\
\hline empathy & $32.43 \%$ & $\mathbf{2 8 . 4 3 \%}$ \\
\hline ambition & $26.58 \%$ & $\mathbf{2 8 . 4 3 \%}$ \\
\hline intelligence & $30.63 \%$ & $\mathbf{2 6 . 4 7 \%}$ \\
\hline trustworthiness & $38.29 \%$ & $\mathbf{2 5 . 4 9 \%}$ \\
\hline high competences & $46.40 \%$ & \\
\hline & & $\mathbf{2 5 . 4 9 \%}$ \\
\hline
\end{tabular}

SIGNIFICANCE OF EMOTIONAL INTELLIGENCE

Kamila Skrzypczyńska

Table 2. Ranking of the most important qualities of the leader according to leaders of the largest corporations in the world classified in the Forbes Global 2000 list

Source: authors' own elaboration based on of the ten elements of emotional intelligence defined in the questionnaire, the most important ones include the ability to inspire others (46.08\%), performance orientation $(39.22 \%)$, and motivation (38.24). All three skills recorded an increase in the number of indications and improved their position in the ranking. 
SIGNIFICANCE OF EMOTIONAL INTELLIGENCE

Kamila Skrzypczyńska

Table 2.

Continued

\begin{tabular}{|c|c|c|}
\hline & Primary results & Results 2018 \\
\hline Quality or skill of a leader & $\begin{array}{l}\text { percentage } \\
\text { of indications }\end{array}$ & $\begin{array}{l}\text { percentage } \\
\text { of indications }\end{array}$ \\
\hline ability to adapt & $27.03 \%$ & $25.49 \%$ \\
\hline loyalty & $23.42 \%$ & $24.51 \%$ \\
\hline tolerance & $24.32 \%$ & $23.53 \%$ \\
\hline courage & $28.38 \%$ & $22.55 \%$ \\
\hline ability to make objective judgements & $34.23 \%$ & $21.57 \%$ \\
\hline straightforwardness & $25.68 \%$ & $16.67 \%$ \\
\hline having intuition & $27.03 \%$ & $16.67 \%$ \\
\hline self-reliance & $23.87 \%$ & $14.71 \%$ \\
\hline sociability & $25.68 \%$ & $13.73 \%$ \\
\hline high-profile imagination & $24.77 \%$ & $13.73 \%$ \\
\hline strong cognitive skills & $24.77 \%$ & $11.76 \%$ \\
\hline persistance & $27.48 \%$ & $10.78 \%$ \\
\hline conservatism & $22.97 \%$ & $10.78 \%$ \\
\hline task-related knowledge & $25.33 \%$ & $9.80 \%$ \\
\hline maturity & $23.42 \%$ & $9.80 \%$ \\
\hline vigilance & $24.77 \%$ & $9.80 \%$ \\
\hline caring for others & $24.77 \%$ & $8.82 \%$ \\
\hline reliability & $34.68 \%$ & $8.82 \%$ \\
\hline extraversion & $27.93 \%$ & $7.84 \%$ \\
\hline dominance & $22.97 \%$ & $7.84 \%$ \\
\hline
\end{tabular}

* rating scale (1-5), where 1 is the highest and 5 is the lowest

The analysis of the dynamics of changes in particular elements of emotional intelligence showed that in the last decade motivation and self-awareness gained the most importance, reaching an indication increase of 8 percentage points. Selfawareness is a necessary, realistic foundation of self-confidence combined with the willingness to continuously self-develop and learn, which in turn influences the level of motivation. Considering that, highly motivated leaders focus on achieving desired results, set themselves difficult goals and take decision risk preceded by a detailed data analysis (Goleman, 2006). A slightly lower increase, almost 7 percentage points, was noted by self-control and willingness to collaborate. This, in turn, illustrates the transformation of expectations towards the leader concerning their relations with others. The importance of emotional maturity, which consists in the control of one's own emotions, is increasingly emphasized. 
Emotional maturity is a prerequisite for effective collaboration, the importance of which is perceived much more explicitly.

Four downward trends were also observed. These involved aspects such as the ability to influence others, self-confidence or empathy. However, in comparison with the dynamics of changes in the individual traits of leaders, these decreases are insignificant. It turns out that the greatest decrease in percentage indications has been marked in the last 10 years for the following traits: vigilance, reliability, dominance, extrovertism, maturity, strong cognitive skills, task-based knowledge and care for others, and even high competences.

Out of 42 assessed attributes, only 13 noted an increase in the number of respondents whereas 29 marked a decrease. This suggests that over the past decade leaders have begun to see the leader's profile more sharply, attributing fewer qualities to them and thus making their role more concrete. Interestingly, among these 13 attributes whose importance has increased, as many as 6 are the elements of emotional intelligence. This allows to conclude that EI is playing a growing role not only in the management theory but also in the awareness of practitioners.

To conclude, the importance of emotional intelligence in business is high and still growing since the appearance of first research and theories in this area. The very concept of emotional intelligence and its internal structure is still evolving, just as it is in the case of leadership. The development of both areas and their interaction as well as varying attitudes of scientists make it difficult to clearly define the boundary and to determine with the application of hard indicators to what extent emotional intelligence determines the effectiveness of leadership. Its undeniable elements are important attributes of leadership and are highly desirable among managerial and other competences, even though they are not mentioned in CVs and recruitment advertisements. The level of emotional intelligence helps to organize own and other employees' work and fosters networking based on healthy relationships. A manager with high EQ is able to shape the working atmosphere fostering problem or even conflict resolution. By passing their own positive emotions and trust in their employees, which manifests itself in inspiring workers to be creative, to develop and even to make mistakes, such a manager creates a lasting, success-oriented organisational culture.

\section{Notes}

[1] In both primary and secondary research, leaders of two thousand of the world's largest Forbes Global 2000 companies from 2006 and 2016 respectively were the target group. The research was carried out using the postal survey method (additionally, the primary research was supported by e-mail reminders; however, due to the relatively low e-mail response in the secondary research, this practice was abandoned). The original survey was preceded by a pilot study to verify the validity of the test instrument. 
SIGNIFICANCE OF EMOTIONAL INTELLIGENCE

Kamila Skrzypczyńska

\section{References}

Aitken, P, Higgs, M. (2010), Developing Change Leaders. The Principles and Practices of Change Leadership Development, Elsevier, Oxford.

Azouzi, A.M., Jarboui, A. (2014), "CEO Emotional Intelligence and Firms' Financial Policies. Bayesian Network Method", Contemporary Economics, Vol. 8 No. 1, pp. 5-24.

Bar-On, R. (1997), EQ-I Bar-On Emotional Quotient Inventory. A measure of emotional intelligence. User's manual, Multi Health Systems, Toronto.

Bar-On, R. (2001), "Emotional intelligence and self-actualization", in: Ciarrochi, J., Forgas, J.P., Mayer, J.D. (Eds.), Emotional intelligence in everyday life, Psychology Press, Philadelphia, pp. 82-97.

Bass, B.M. (1990), Bass and Stodgill's Handbook of Leadership, Free Press, New York.

Ciarrochi, J.V., Chan, A.Y.C., Bajgar, J. (2001), "Measuring emotional intelligence in adolescents", Personality and individual differences, No. 31, pp. 1105-1119.

Ciarrochi, J.V., Chan, A.Y.C., Caputi, P. (2000), "A critical evaluation of the emotional intelligence construct", Personality and Individual differences, No. 28, pp. 539-561.

Dabke, D. (2016), "Impact of Leader's Emotional Intelligence and Transformational Behavior on Perceived Leadership Effectiveness: A Multiple Source View", Business Perspectives and Research, Vol. 4 No. 1, pp. 27-40.

Fiedeldey-Van Dijk, C., Freedman, J. (2007), "Differentiating emotional intelligence in leadership", Journal of Leadership Studies, Vol. 1 No. 2, pp 8-20.

Fiedler, F.E. (1995), "Reflections by an accidental theorist", Leadership Quarterly, Vol. 6 No. 4, pp. 453-461.

Fleishman, E.A., Mumford, M.D., Zaccaro, S.J., Levin, K.Y, Korotkin, A.L., Hein, M.B. (1991), "Taxonomic efforts in the description of leader behavior: A synthesis and functional interpretation", Leadership Quarterly, Vol. 2 No. 4, pp. 245-287.

Gandolfi, F., Stone, S. (2016), "Clarifying leadership: high-impact leaders in a time of leadership crisis", Review of International Comparative Management, Vol. 17, No. 3, pp. 212-224.

Goleman D. (1990), Inteligencja emocjonalna, Media Rodzina, Poznań.

Goleman D. (1999), Inteligencja emocjonalna w praktyce, Media Rodzina, Poznań.

Goleman D. (2006), Przywództwo, które przynosi efekty, in: Atrybuty przywódcy - Harvard Business Review Press, Gliwice.

HernezBroome, G., Hughes, R.L. (2004), "Leadership Development: Past, Present, and Future", Human Resource Planning, Vol. 27 No. 1, pp. 24-32.

Hersey, P., Blanchard, K. (1996), Management of Organizational Behavior: Utilizing Human Resources, Englewood Cliffs.

Judge, T.A., LePine, J.A. (2007), "The bright and dark sides of personality: Implications for personnel selection in individual and team contexts", in: Langan-Foz, R.J., Cooper, J., Klimoski, C.L. (Eds.), Research companion to the dysfunctional workplace: Management challenges and symptoms, Edward Elgar, Cheltenham.

Judge, T.A., Piccolo, R.F., Kosalka, T.A. (2009), "The bright and dark sides of leader traits: A review and theoretical extension of the leader trait paradigm", Leadership Quarterly, Vol. 20 No. 6, pp. 855-875. 
Kaplan, R.E. (1991), Beyond Ambition: How Driven Managers Can Lead Better and Live Better, Jossey-Bass, San Francisco.

Karaszewski, R., Drewniak, R., Skrzypczyńska, K. (2019), Ewolucja przywództwa, TNOiK, Toruń.

SIGNIFICANCE OF EMOTIONAL INTELLIGENCE

Kamila Skrzypczyńska

Karaszewski, R., Drewniak, R., Skrzypczyńska, K. (2019), Perspektywy rozwoju przywództwa w biznesie korporacyjnym, TNOiK, Toruń.

Kerr, R., Garvin, J., Heaton, N., Boyle, E. (2006), "Emotional intelligence and leadership effectiveness", Leadership \& Organization Development Journal, Vol. 27 No. 4, pp. 265-279.

Mayer, J.D., Salovey, P., Caruso, D., Sitarenions, G. (2001), 'Emotional Inteligence as a strandard intelligence", Emotion, Vol. 1 No. 3, pp. 232-242.

Mayer, J.D., Salovey, P., Caruso, D.R. (2000), Models of emotional intelligence, in: Sternberg, R.J. (Ed.), Handbook of intelligence, Cambridge University Press, Cambridge.

McCrae, R.R., Costa Jr., P.T. (2005), Osobowość człowieka dorosłego, Wydawnictwo WAM, Kraków.

Neubauer, A.C., Freudenthaler, H.H. (2005), Models of emotional intelligence, in: Schulze, W.R., Roberts, R.D. (Eds.), Emotional intelligence: an international handbook, Hogrefe \& Hubner Publishers, Gottingen, pp. 31-50.

Northouse, P.G. (2003), Leadership: Theory and practice, Thousand Oaks.

Opolska, A. (2014), Osobowość, kompetencje społeczne i inteligencja emocjonalna menedżerów. Determinanty stylu kierowania, Wydawnictwo CeDeWu, Warszawa.

Posner, B.Z. (2015), "An investigation into the leadership practices of volunteer leaders", Leadership \& Organization Development Journal, Vol. 36 No. 7, pp. 885-898.

Salgado, J. (2002), "The Big Five personality dimensions and counterproductive behaviors", International Journal of Selection and Assessment, Vol. 10 No. 1-2, pp. 117-125.

Salovey, P. (2001), "Applied emotional intelligence: regulating emotions to become healthy, wealthy and wise", in: Ciarrochi, J., Forgas, J.P., Mayer, J.D. (Ed.), Emotional intelligence in everyday life: a scientific inquiry, Psychology Press, Taylor \& Francis Group, Philadelphia, pp. 168-184.

Salovey, P., Mayer, J.D. (1990), "Emotional intelligence”, Imagination Cognition and Personality, Vol. 9 No. 3, pp. 185-211.

Salovey, P., Mayer, J.D. (1999), “Czym jest inteligencja emocjonalna?”, in: Salovey, P., Sluyter, D.J. (Eds.), Rozwój emocjonalny a inteligencja emocjonalna, Dom Wydawniczy Rebis, Poznań, pp. 23-69.

Schutte, N.S., Malouff, J.M., Bobik, C., Coston, T.D., Greeson, C., Jedlicka, C., Rhodes, E., Wendorf, G. (2001), "Emotional intelligence and interpersonal relations", The Journal of Social Psychology, Vol. 141 No. 4, pp. 523-536.

Seters, D.A., Field, R.H.G. (1990), “The Evolution of Leadership Theory”, Journal of Organizational Change Management, Vol. 3 No. 3, pp. 29-45.

Wu, W.L., Lee, Y.C. (2017), "Empowering group leaders encourages knowledge sharing: integrating the social exchange theory and positive organizational behavior perspective", Journal of Knowledge Management, Vol. 21 No. 2, pp. 474-491.

Yukl, G. (2010), Leadership in organizations, Prentice Hall, Upper Saddle River. 
SIGNIFICANCE

OF EMOTIONAL

INTELLIGENCE

Kamila Skrzypczyńska
Zareen, M., Razzaq, K., Mujtaba, B.G. (2014), Impact of Transactional, Transformational and Laisser-Faire Leadership Styles on Motivation: A Quantitative Study of Banking Employees in Pakistan, Business Media, New York.

Zigarmi, D., Roberts, T.P., Randolph W.A. (2015), "Employees' Perceived Use of Leader Power and Implications for Affect and Work Intentions", Human Resource Development Quarterly, Vol. 26 No. 4, pp. 359-384. 